\title{
Community Music Education on the Background of Constructing Harmonious Community
}

\author{
Ling Xu \\ College of Art and Communication, Bohai University, Jinzhou, P.R. China \\ 105432750@qq.com
}

Keywords: harmonious community; music education; content; effect; problem; proposal

\begin{abstract}
Building a harmonious community is an important part for building a harmonious society, and strives to build social life community that with orderly management, improving service, beautiful environment, good security, convenience, harmonious interpersonal and the harmonious social groups. As a part of lifelong education, community music education plays an increasingly important role, it is necessary to protect the community cultural development and community cultural activities. This paper analyzes the content of building a harmonious community, and discusses the role of community music education, pointed out the problems existed in the music education community, proposed the proposal that developing community music education. Results of this study solve the key problem of community music education, plays an important role to promote the construction of harmonious community.
\end{abstract}

\section{Introduction}

Community is that some social groups or social organizations gathered in one area formed large collective life, is the basic content of the social organism, and is a microcosm of the macro society. Community should include demographic, geographic range, and certain types of tissue culture and a certain scale facilities, certain characteristics of a certain number. The community is the cells of the city, is the basis of urban management, and is a social life community with multiple functional territorial, is visible and tangible reality individuals. Harmonious community is the foundation of a harmonious society. Starting from the construction of a harmonious community, so that the community plays service role in improving the living standards and quality and plays a role as a bridge in relations between the party and the masses, to play a catalytic role in maintaining social stability and creating a good environment to live and work for the masses.

Community culture as an important part of the social elements, in the development process of the modern material and spiritual civilization, with its unique content and form penetrated more human society, economy culture, traditions, aesthetic, emotional and ideological exchanges. Building a socialist harmonious society, community culture construction is an important element, and building a harmonious society also needs to guide and support from community culture. More harmonious society is developing and more prominent for the position and role of community culture. Community music education belongs to a branch of the education system, because of its special social functions and derived social effects, will have an important impact on building harmonious society.

\section{Contents on Constructing Harmonious Community}

Harmonious community construction refers to Deng Xiaoping Theory and the important thought of "Three Represents" as guidance, comprehensively implement the scientific concept of development, and strive to build a community orderly management, improve service, beautiful environment, good security, convenience, interpersonal harmony the various social groups in harmony social life community. The basic principles of building a socialist harmonious society is: adhere to the people-oriented, scientific development, persist in reform and opening up, adhere to the democratic rule of law, adhere to the reform, development and stability, and adhere to build the whole society under the leadership of the party. Building a harmonious community to adhere to these principles on 
the basis of, but also insist on fairness and justice, community autonomy, community participation and multi-party collaborative everything from reality principles. Although the practice of building a harmonious community of content is not consistent, but generally includes the following items:

(1) Resident autonomy. Principles of community residents in the community through some form of organization, the implementation of election, democratic decision making, democratic management and democratic supervision of democracy, according to community residents "to manage their own thing," "we thing we do" through democratic consultative manner together to solve problems in the community in public affairs and public welfare, etc., and jointly create a happy life.

(2) Community services. Directly provide public services and other substance, culture and life aspects of services to members of the community, it will help continue to meet residents' needs. Now need to focus on community service is: for the masses of convenient services for special groups of social assistance, social welfare and special care and support services, for the re-employment of laid-off workers and social security services.

(3) Community culture [1]. It is the sum of the members of the community mental activity, lifestyle and behavioral norms. Community cultural construction in rich and vibrant cultural life and to meet the growing spiritual and cultural needs of the masses for the purpose, including a variety of mass culture, sports, science, education and recreational activities to improve the overall quality of community culture and community team members, promote community members to form a healthy, civilized and scientific way of life.

(4) Community safety. Is building a moderately prosperous society and building a harmonious society and an important part of social peace is to implement people-oriented, comprehensive, coordinated and scientific development concept, one of the important measures of sustainable development. Carry out safety promotion activities to promote safety culture and safety of scientific and technological knowledge, improve staff security awareness and prevention capabilities, the formation of community authorities, businesses, volunteers and individuals to participate in the mechanism.

(5) Community environment. Is the sum to be generated by natural conditions, social conditions, cultural and economic conditions of that the Community body's survival and community activity. Mainly include community environmental health, community greening the environment and community environmental remediation. To adopt an integrated approach to governance, and actively improve infrastructure, reduce pollution, and strengthen the environmental management system and environmental sanitation responsibility, environmental awareness of community members.

\section{Effect on Community Music Education}

Community music education is music talents, music lovers, the community and community members combined, doped with a musical education in the form of school education and social organizations, and many other factors. Similarities and school music education is: Aesthetics as the core, to promote community members aesthetic capacity increased, to improve the effectiveness of social individual musicianship and musical cultural level, and ultimately to promote the comprehensive development of human beings; differs school music education are: no special education system, not for the purpose to obtain a degree, the main purpose of people to participate in community music education is entertainment itself. Community music education as a whole subsystem of social education, can own special and unique form of social action, acting on the residents of the community, to serve the community the harmonious development of the building and sustainable development, a positive impact on building a harmonious society. Specific role in the following aspects:

(1) Train community member's aesthetic consciousness [2]. Aesthetic is a basic and fundamental core philosophy of music education. In community music education, can enhance the aesthetic sense of community residents, improve the aesthetic ability of community residents, community residents to participate in musical activities, listen to music, music performance and music creation, 
to experience the beauty of music and the music brings pleasure, so that people feel good, relaxed and comfortable, by the musical charm of infection on life and things around longing generate optimism of love, enlighten their intelligence, purify their hearts, whereby residents a better culture and aesthetic taste healthy.

(2) Promote national music heritage. Community Music Education and Inheritance of National Music is a complementary relationship. Ethnic music is an important part of Chinese culture and long history. Educated community music education is mainly the elderly, poor acceptance of popular music; there are some difficulties in the understanding of Western music. Thus, most of the music education community is based on ethnic music. Community Music Education and local traditions and opera and other music playing and singing together, the use of folk music generous mass base, but also make people more receptive to community music education.

(3) Provide a variety of leisure and entertainment. In the well-being of harmonious social environment, community residents' daily life as a region of space, active in community musical events as an important part of the cultural community, people in the community become relatively popular as a high quality leisure entertainment, people relaxed and happy by aesthetic enjoyment to save energy and vitality. By organizing music festival, concert, musical societies routine exercise, music and dance music competitions and other social activities, so that residents get the spirit of joy and mental relaxation in the aesthetic experience.

\section{Existing Problems on Community Music Education}

Community music education in their vivid visual form of education, lively and interesting educational content loved by the masses, has become one of the best forms of education in the community education likely to be accepted. The current community music education has made gratifying achievements, community cultural activities in various forms of music, all the people rich learning content Auditorium, rich network resources for lifelong learning, and healthy development while also following problems [3-5]:

(1) Education funding is more. Due to community education has the characteristics of non-profit, community education development funds mainly rely on government funding. However, most government education funding into basic education and higher education, although some funds are invested to finance the construction of the community, but the community is mainly hardware facilities and site construction, government funding of community education was really very small. Coupled with community education in many parts of the publicity is not in place, the role has not been fully exploited, do not pay attention subjective causing other social organizations, community education funding support is not enough, many enterprises and institutions within the community, personal active participation of community education not high, low financing, a single source of funding, relying solely on the annual amount of government investment, shortage of funds has seriously hampered the normal development of community education work.

(2) The lack of qualified teachers. Teachers dominant in the education of many factors, is an important factor affecting education. Community Music Education community-based music events, community music teachers and school music teachers are very different. Currently, it plays an important role in community music education in teachers, most enthusiastic music lovers, some of which have a certain expertise, and some just for music understanding. Thus, the existence of serious problems in the community music education is the lack of teachers and the lack of professional skills. At the same time, community music teachers greater mobility, but also affect the long-term development of community music education. How to transform entertain form into with a higher level of professional education, it is a question worth considering.

(3) Regulatory system is imperfect. The legal system is a unified whole consists of all existing legal norms, according to the classification of the legal department of different combinations to form a system of organic links. Community management work-related laws and regulations include constitutional, administrative regulations, civil law and contract law. For lack of legal regulations, community education, community music education development is very unfavorable. At present, most art lovers community music education is spontaneous activity, the lack of appropriate legal 
and policy guidance, there is no specific standards and norms, can not lead to community music education activities carried out smoothly in accordance with the people's hope in the form of, or in carrying out the process of the emergence of various all sorts of problems.

(4) Lack of systematic global planning. Community Education with a sound system of lifelong education, to meet the national need for lifelong learning and service in community building and cultural heritage, coordinate social functions, many functions have political, social, cultural and economic. But most affected by the current wave of the city in pursuit of economic development, community education services in economic development has become an auxiliary tool, has lost its design positioning community education in the social and cultural aspects of the lack of systematic global planning, most community education activities still remain in the bull management level, part of the work deviates from the learning needs of learners, community education programs undertaken does not fully take into account the actual needs of the knowledge base and educated population of the city, sometimes just to meet performance needs, community education administration needs to become what, people are going to learn what formalism education.

\section{Proposals on Development of Community Music Education}

Characteristics of community music education, music education determines the development community is inseparable from the vast number of participants in the joint efforts of a wide range of support and funding is inseparable from social pull, but also inseparable standardize and guide the relevant departments. Reference to the relevant research results [6-9], proposals on development of community music education recommendations are as follows:

(1) Play a guiding role of advanced theory. Community Music Education develop without the support and guidance of advanced theory, China's current low level of theory in this regard, can not meet the needs of rapid development of music education community must take foreign advanced theory embracing, absorbing, specific measures include: foothold on independent innovation, according to the Chinese reality, creating community music education theory with Chinese characteristics; dialectical absorption, flexibility, in order to promote the practice of theoretical innovation; organizing music international academic meetings, communication and foreign, to promote Chinese community music education theory rapidly. Because of that community music education theory directly affects the mental health for residents, and then plays a decisive role on the construction of spiritual civilization. Since our theory is still in its infancy, a large gap with foreign countries, in theory, does so first with international standards, to keep up with the pace of international, and then seek innovation and beyond.

(2) Give full play to promote the role of local colleges and universities. Local rich educational resources universities, having regard manpower, equipment, facilities, sites and information resources and other advantages, community music education development process, the demand for these resources and very strong, therefore, should give full play to the advantages of local colleges and universities on educational resources, so the community music education for promoting the development of good momentum and support. With the progress and development of society, the community has become more sophisticated, the demand for community music education growing, full use of university resources for the local community services, with positive long-term development community music education. Specific measures include the following three aspects: First, local colleges and universities into the community, for the community to provide comprehensive music education resources; Second, grass-roots government to increase investment, funding and resources and support for community music development; Third, community residents public participation, and actively involved in the community music career developed.

(3) Increasing government support. Community education has become an important part of lifelong education, in community music education without the support and guidance of the relevant government departments. From the development process of countries in community music education, government support and guidance is a necessary condition indispensable. Government support and funding efforts is the key to music community health education, sustainable development. Cultural promotion and other related departments should give full play to the 
functions of management, there is conducive to the development of community music education activities to promote social and cultural development, promote spiritual civilization construction pace of policy guidelines, the majority of the people's growing spiritual and cultural needs are met. Encourage the development of community and music culture, to give support in terms of funding, to give care in the emotional direction. Establish coordination between the various departments unified transport mechanism, co-management and community into his musical education.

(4) Actively cultivate music professionals. The current community music event organizers and team members, mostly due to their interests come together; the participants are not professional musical talents. But the music community to achieve sustainable development and the need of professional musicians, so inevitably the introduction of professional training and musical talents, promote community music education levels increase. Specific measures can be: proactive talent introduction policy, and fully mobilize outstanding graduates into the community to work in music education enthusiasm; relevant departments regularly organize training activities for community music education institution personnel, improve the professional level; between neighboring communities personnel exchanges, to promote diversity and to raise the level of the music community, while fostering comprehensive round talent; talent team selection and training of community music education.

(5) Educational function of new media. New media refers to new forms different from radio, television, newspapers and magazines and other traditional media, the use of digital technology and network technology, the Internet, broadband LAN, wireless communication network and satellite channels, as well as computers, mobile phones and digital television sets terminal, to provide users with communication pattern information and entertainment services. The new media has covered the breadth of information, real-time information dissemination, exchange of information and interactive content complexity and so on. To give full play to the new media education and guidance functions to improve media literacy community residents. Community music education for all members of the community can make use of new media platforms in community music education, the establishment of community official We Chat and micro blogging, the establishment of specialized in community music education in micro-channel micro-Bo, by sending information to share music education articles and videos, etc., promote community music education.

\section{Conclusion}

Community music education is music education activity that carries out by music professionals, music lovers and community music groups. Community music education promotes coordination and the simultaneous development of urban economy and urban construction of spiritual civilization, and creating an enabling environment for development and building a learning cultural community. As people's living standards improve, more and more intense spiritual and cultural needs, and actively carry out various cultural arts education in the community, can effectively meet the cultural needs of the people, rich people's leisure life. Building a learning community, learning to actively strengthen individuals, families and links learning and other aspects of social learning, through the efforts of all aspects of cooperation and strengthen the foundation for the development of arts and culture, building a harmonious society to provide the necessary material guarantee. Community music education development in China, has a fine cultural traditions and deep cultural roots, there is a big potential for development. Community Music Education is an important force in national music heritage, community music education related to the inheritance and development of national music. Results of this study, to find a suitable characteristic of China's development road community music education will play an active role in promoting. 


\section{References}

[1] Xinjiang party building network, "What is the main content of the construction of harmonious community," http://www.xjkunlun.cn/zzgz/jczzjs/2012/2392440.htm, 2016-9-20.

[2] D. N. Zhang, Z. J. Tu, "Function of Community Music Education," Journal of Guizhou University of Technology(Social Science Edition), vol. 9, no. 5, pp. 183-185, 2007.

[3] Y. Li, "An Analysis of the Present Situation and Development Strategy of Community Music Education in Taiyuan," Theory and Practice of Education, vol. 35, no. 6, pp. 62-64, 2015.

[4] M. Li, "Community Music Education Mechanism in China," Journal of Shenyang University(Social Science), vol. 17, no. 2, pp. 119-221, 2015.

[5] C. Huang, "The present situation and development of community music education in our country," Engineering Master's Degree of Tianjin Conservatory of Music, 2010.

[6] X. Ding, "Strategies for Using Education Resources in Local Colleges and Universities to Develop Community Music Education," Journal of Shaoxing University, vol. 36, no. 11, pp. 53-55, 2016.

[7] Y. F. Liu, K. F. Wwng, "On the social education function of the new media," Journalism Probe, vol. 16, no. 3, pp. 153-153, 2016.

[8] Z. L. Hu, "The study of music education in urban community: Based on the investigation of some community music activities in Shanghai," Engineering Master's Degree of Shanghai Conservatory of Music, 2012.

[9] M. J. Li, Y. L. Zhang, "On the development of community music education in China," Home Drama, vol. 15, no. 8, pp. 85-86, 2015. 